\section{NEOLIBERALISM VERSUS SOVEREIGNTY: THE CASE OF SRI LANKA}

\section{Tamara Kunanayakam}

Economist and International Relations Expert,

Former Ambassador/Permanent Representative of Sri Lanka to the United Nations at Geneva, Former Senior International Civil Servant at the United Nations, and Ex-Chairperson/Rapporteur UN Intergovernmental Working Group on the Right to Development
Sri Lanka Journal of

Economic Research Volume 6(1) November 2018

SLJER.06.01.P: pp.125-146.

Sri Lanka Forum of University Economists

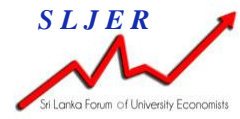

\title{
INTRODUCTION
}

A fundamental principle of international law, incorporated in a wide range of international and regional instruments, is permanent sovereignty over the nation's wealth and resources and all its economic activities as a basic constituent of the right of peoples to self-determination and its corollary, the duty of States to respect sovereign equality in their relations with other States. It is a recognition that there can be no political independence without economic, social and cultural independence, "free from all forms of interference or pressure, direct or indirect, of whatever sort and under whatever pretext." "For independence to be complete, any future attempt to restore foreign influence or domination must be prevented forever. ${ }^{2}$ This universal admission is the result of the historical struggle of colonised peoples for freedom, particularly of Africa and Asia, whose newly won independence had remained purely formal and fragile, threatened by the resolve of rich capitalist countries to standardise and rationalise the global economy to ensure their monopoly and control over foreign markets.

The ongoing neoliberal reconfiguration of the State to facilitate global expansion of capital by imposing a single model of development and transferring decision-making on all aspects of social relations to a handful of Western oligarchs is inimical to the sovereignty and independence of nation-States.

The agenda is supported by the neoconservative interests observed in modus operandi of the UN Human Rights Council (led by US neoconservatives) who promote direct,

\footnotetext{
${ }^{1} \mathrm{UN}$ Declaration on the Granting of Independence to Colonial Countries and Peoples, General Assembly resolution 1514 (XV) of 14 December 1960.

${ }^{2}$ For a more detailed examination of the relevant principles contained in United Nations documents since 1944, see Tamara Kunanayakam, Historical analysis of the principles contained in the Declaration on the Right to Development, UN document HR/RD/1990/CONF.1, Geneva, 1990; Tamara Kunanayakam, The Declaration on the Right to Development in the context of United Nations standard-setting, Realizing the right to development : essays in commemoration of 25 years of the United Nations Declaration on the Right to Development. United Nations, 2013; and, Quel développement? Quelle coopération internationale? Third World Centre (CETIM), Geneva, 2007.
} 
unilateral, preventive, and pre-emptive intervention, including military, in the internal affairs of sovereign States.

In examining the rapid progress of neoliberal reforms in Sri Lanka, it is essential to bear in mind this complementarity and commonality between neoliberals and neoconservatives, and their mutually reinforcing actions: their common goal is to maintain US global hegemony, and their common enemy is State sovereignty, the principle upon which the multilateral system is based $;^{3}$ they both champion a shift of governance to corporate-controlled supranational institutions ${ }^{4}$ they claim are necessarily objective and apolitical, although beyond the reach of domestic accountability; they both foster elite cooperation globally through powerful, often secretive, groups $;^{5}$ and, both make claims to a 'moral universalism' to justify external intervention, refining and propagating language best described as Orwellian doublespeak to promote their agenda.

The sovereignty of nations and peoples everywhere is at stake, and Sri Lanka is no exception. The present paper counters the neoliberal claim that the breaking down of nation-States and sovereignty is a natural phenomenon that is progressive and inevitable, and shows how its making and perpetuation is a continuing violation of national sovereignty and the inalienable rights of peoples and nations to determine their political, economic, social and cultural systems.

The paper begins by examining the making of the neoliberal global order by a conscious restructuring of the nation-State and the fostering of elite cooperation internationally to ensure its reproduction through, inter alia, think tanks. It will then examine some of neoliberalism's basic claims and reality, and its impact on politics and society. Finally, it will examine the case of Sri Lanka and attempt to disentangle the complex web of relations that exist between and among think tanks, the 'mother of all think tanks' - the Mont Pelerin Society (MPS), global corporates, the US Administration, and Sri Lanka's transnationalised elite. The section will focus on some of the lesser known, but visible, vehicles for intervention - the Institute for Policy Studies (IPS), Advocata Institute, and Millenium Challenge Corporation (MCC). It will conclude with certain observations on fundamental principles of international law that provide a basis for alternatives to the hegemonic neoliberal model, for the restoration of sovereignty.

\footnotetext{
${ }^{3}$ Frequent attacks against sovereignty can be seen in the body of neoclassical economic theory and neoconservative philosophy that influenced the development of neoliberalism.

${ }^{4}$ Such as the already existing World Trade Organisation, IMF/World Bank, international free trade agreements, etc.

${ }^{5}$ For instance, the Bilderberg Group, the Trilateral Commission, the Council of Foreign Relations, and Project for the New American Century (PNAC).
} 


\section{NEOLIBERAL RE-ENGINEERING OF STATE: A POLITICAL PROJECT}

An insidious, radical and all-encompassing transformation or re-engineering of the nation-State is taking place based on a 'market society' and 'market rules,' involving the marketization of the entire scope of human relations through multiple political, economic, social and cultural processes.

It is not a natural, self-regulating, inevitable and benevolent process, but designed, implemented and reproduced, often through violent intervention, by global corporations in alliance with a section of the local elite, whose destiny and vision have become intertwined with theirs. Its name is neoliberalism, the global expression of capital dominated by finance. Its principal project is 'globalisation' - the integration of the world into new globalised circuits of accumulation for profit maximization by transnational capital dominated by finance through use of State power. It is associated with the US project to retain global hegemony, if necessary by unilateral military intervention. Unlike classical liberalism, it goes beyond the mere opening of markets. Its claim is global, a single model for all, imposing the 'market logic' to all forms of human interaction, economic as well as financial, social, political, cultural, ecological, and even psychological.

Neoliberalism cannot be separated from capitalism. Roberts describes it a "new regimen of capitalism" as political response of capital to the growing militancy of the labour force ${ }^{6}$ and Saad-Filho as 'the mode of existence of contemporary capitalism ${ }^{7}$ to curtail the power of labour. As such, it emerged in reaction to the first generalised systemic crisis of world capitalism in 1973-1974 resulting from a falling rate of profit expressed in a crisis of overproduction, a credit crisis in the US aggravated by escalating costs of its military interventions in Korea, Taiwan and Vietnam, the collapse of the Bretton Woods system, stagflation, and an impending debt crisis in the South.

Ever since, it has been imposed globally, often violently, through State intervention and patronage of US hegemony The first neoliberal experiment, designed and implemented by Milton Friedman's Chicago Boys, was carried out in Chile from 1973 to 1989 under the military dictatorship of General Pinochet, following the CIA-backed coup d'état and assassination of the democratically elected President Salvador Allende. It gained prominence only after the election of Margaret Thatcher in Britain and Ronald Reagan in the United States. In the Global South, it was imposed through external pressure ranging

\footnotetext{
${ }^{6}$ See Michael Roberts, The Great Recession, 2009.

${ }^{7}$ See Alfredo Saad-Filho, Crisis in neoliberalism or crisis of neoliberalism? Socialist Register, 2011. See also Ben Fine and Alfredo Saad-Filho, Thirteen Things You Need to Know About Neoliberalism, Critical Sociology, 43 (4-5), 2016 \& Damien Cahill and Alfredo Saad-Filho, Introduction: Neoliberalism Since the Crisis, Critical Sociology Vol. 43 (4-5), 2017.
} 
from IMF/World Bank conditionalities, unilateral threats and sanctions, financing of civil society organisations promoting neoliberal values, fomenting political unrest and regime change, foreign aggression, and military intervention.

Contrary to neoliberal claims, 'markets' are not places where goods and services are freely bought and sold by producers and consumers, but where large corporations dominate unhindered by regulation or countervailing social forces. They rely on a strong State to create favourable conditions for the operation of transnational capital. In fact, neoliberalism is based on "the systematic use of State power to impose a hegemonic project of recomposition of the rule of capital;" 8 "nonintervention' is only the ideological guise. As Gramsci understood, "laissez faire too is a form of State 'regulation' introduced and maintained by coercive means. It is a deliberate policy, conscious of its own ends, and not the spontaneous automatic expression of economic facts. " 9 Instead of being rolled back or made to disappear, the State is reengineered to intervene on its own behalf.

The State is expected to intervene heavily to deregulate (liberalise, depoliticise, privatise, outsource, flexibilise, and marketise everything) and implement fiscal and monetary austerity with a view to separating from the political realm all economic/financial and other potentially profitable activities, including social and cultural, so that vital sectors are brought under the control of transnational capital and its economic interests prioritised over the common good, insulating it from peoples' choices, crippling trade unions, and depriving the State of capacity to act. Once deregulated, the State is expected to reregulate to protect the private property thus acquired by global corporates to shield it from popular resistance and trade union action. 'Good Governance' (and the associated 'Rule of Law') is the obscure term for a new system of law and government involving legal, political and institutional reform, putting in place instruments of social control-coercive and ideological - to maintain a "stable social order' required by global capital, thus limiting the ability of people and nation to make choices and State capacity to implement those choices and promote social justice, or even to fulfill its international human rights and labour obligations.

Implicit in the dogma of an autonomous free market as optimum for achieving human freedom and a collectivist State as a threat is the view that it is not society that determines the economic system, but the economic system that determines how society is organised, ${ }^{10}$ This notion of a mystic entity beyond human control removes decision

\footnotetext{
${ }^{8}$ See Alfredo Saad-Filho, Crisis in neoliberalism or crisis of neoliberalism?, op.cit.

${ }^{9}$ Antonio Gramsci, "The Modern Prince" The Prison Notebooks

${ }^{10}$ Karl Polanyi described it as a system in which '[i]nstead of economy being embedded in social relations, social relations are embedded in the economic system.' See K. Polanyi, The Great Transformation: The Political and Economic Origins of Our Times. Boston: Beacon Press, 2001.
} 
making from the lives of ordinary people and renders them passive objects, not subjects of their own destiny. It thus permits the imposition of an alien model of society on peoples and nations usurping their inalienable right to freely determine the political, economic, social and cultural system they choose to live in.

Neoliberalism is essentially a political project designed to prevent the emergence of countervailing forces and permit transnational capital to override democratic processes, determine national economic and social priorities, and secure control over the value of what is produced by the nation, its wealth, natural resources, economic activities, workforce, and currency. On the part of the local allies, it implies abdication of State power and its duty to act on behalf of nation and people.

\section{GLOBAL ELITE NETWORK FOR REPRODUCTION OF NEOLIBERALISM}

Transnational capital has put in place an impressive global elite network to foster cooperation internationally to support its global expansion and reproduction. Its beginnings can be traced to the Mont Pelerin Society (MPS) founded in 1947 by Friedrich von Hayek of the Austrian School of Economics, along with Milton Friedman of the Chicago School who became Economic Adviser to US President Ronald Reagan, Allan Walters who became Chief Economic Adviser to British Prime Minister Margaret Thatcher, other neoliberals and members of the US oligarchy and European aristocracy. The funding came from millionaires and their foundations. It was only a quarter century later, however, that the opportunity arose for its ideologues to assume positions of State power with the monetary school associated with Milton Friedman and the 'Chicago Boys' gaining the support of the ruling class in the early 1980s to restructure the capitalist system and restore capital accumulation.

MPS is a powerful elite-led global policy-planning network of over 500 think tanks and numerous business schools, corporate-backed Foundations, media, and University economics departments transformed into ideological centres of neoliberal strategy. Among them is Atlas Economic Research Foundation (Atlas Network), American Enterprise Institute, Heritage Foundation, the Cato Institute, Institute of Economic Affairs, Centre for Policy Studies and the Adam Smith Institute. Most were founded and run with the help of at least one MPS member. ${ }^{11}$

\footnotetext{
${ }^{11}$ For studies of MPS think tanks, see Bernhard Walpen, Die offenen Feinde und ihre Gesellschaft : Eine hegemonietheoretische Studie zur Mont Pelerin Society, VSA Verlag, Hamburg 2004; Dieter Plehwe, Bernhard Walpen and Gisela Neuhöffer (eds.), Neoliberal Hegemony: A Global Critique, Routledge, London and New York, 2006; Philip Mirowski and Dieter Plehwe (eds),op.cit.; and, Marie Laure Djelic, Spreading Ideas to Change the World - Inventing and Institutionalizing the Neoliberal Think Tank, ESSEC Business School, 8 September 2014.
} 
Atlas, a network of some 500 organizations in 96 countries functions as strategic link between MPS and neoliberal think tanks and is the cornerstone for the organizational deployment, diffusion and activation of the ideology worldwide. It was created by MPS member Antony Fisher with the support of Milton Friedman and Margaret Thatcher; its mission, "to litter the world with free-market think tanks" and disseminate an organizational blueprint to activate the ideology with global ambitions. ${ }^{12}$ Atlas has been involved in regime change and destabilisation in especially Latin America ${ }^{13}$ and Eastern Europe, functioning as an extension of US foreign policy. Corporates are an important source of Atlas funding. ${ }^{14}$ A senior fellow at Atlas, Judy Shelton, ${ }^{15}$ who was adviser to Trump's Presidential campaign, chairs the National Endowment for Democracy created in 1983 by US President Reagan as a permanent funding mechanism to support private organizations that would engage in propaganda and political action that the CIA had historically organized and paid for covertly. ${ }^{16}$ Atlas is also associate member of the State Policy Network (SPN), a web of right-wing think tanks largely funded by global corporations. ${ }^{17}$

These "secondhand dealers in ideas" as Hayek called them, produce, spread, entrench and, in times of crisis, defend the neoliberal dogma, contributing to an omnipresent

\footnotetext{
${ }^{12}$ See Marie-Laure Djelic and Reza Mousavi, Constructing an Organizational Architecture for the Transnational Diffusion of Ideologies - The Case of Atlas and Neoliberalism, ESSEC Business School, 2016; David Harvey, A Brief History of Neoliberalism, Oxford: Oxford University Press, 2005, and, Ola Innset, Reinventing Liberalismispes: Early Neoliberalism in Context, 1920 - 1947, doctoral thesis submitted to European University Institute, Florence, 2017.
}

${ }^{13}$ See Lee Fang, Sphere of influence: how American Libertarians are remaking Latin American politics, The Intercept, 9 August 2017; and, Aram Aharonian, Álvaro Verzi Rangel, The Atlas Network's Insidious Impact on the Ground, News Click, 3 September 2018.

https://www.newsclick.in/atlas-networks-insidious-impact-ground

${ }^{14}$ For a case study, see The atlas network: a "strategic ally" of the tobacco industry, by Julia Smith, Sheryl Thompson and Kelley Lee, in The International Journal of Health Planning and Management, 2017. Published online 28 April 2016 in Wiley Online Library.

15 See National Endowment for Democracy, https://www.ned.org/experts/dr-judy-sheltonchairman/; Judy Shelton: Trump, the Next Fed Chair and the Gold Standard, Gold Investing News, 1 November 2017 https://investingnews.com/daily/resource-investing/precious-metalsinvesting/gold-investing/judy-shelton-trump-gold-standard/ https://www.atlasnetwork.org/about/people/judy-shelton-ph.d

${ }^{16}$ See Robert Parry, Reagan Documents Shed Light on CIA 'Meddling' Abroad, Mintpress News, 15 September 2017. https://www.mintpressnews.com/reagan-documents-shed-light-on-cia-meddlingabroad/232047/, William Blum, Trojan Horse: The National Endowment for Democracy, https://williamblum.org/chapters/rogue-state/trojan-horse-the-national-endowment-for-democracy

${ }^{17}$ See Exposed: The State Policy Network the Powerful Right-Wing Network Helping to Hijack State, Politics and Government, Center for Media and Democracy/Alecesposed.org, 2013. 
ideological framework that misrepresents and justifies the perpetuation of neoliberalism ${ }^{18}$ to make it legitimate. According to Mirowski (2009), they are "not only worried about spreading neoliberal ideas, but also about casting doubt on controversial topics, such as global warming. They deny certain realities, and seek to produce confusion about others."

\section{NEOLIBERAL CLAIMS AND REALITY}

Despite the more than four decades of neoliberalism worldwide, it has failed to demonstrate its claim of market superiority over any form of social organization in terms of efficiency, growth, global prosperity and personal freedom; it has also failed to achieve its goal of maintaining capital accumulation, destroying its very own conditions of existence. $^{19}$

The marketisation of areas to which global corporates did not have access before such as health, education, justice, police, foreign affairs, and their digitalisation with absolute priority to the short term and profitability, is resulting in an unprecedented concentration of wealth, rising inequalities, unemployment, underemployment, poverty, insecurity, ecological destruction, and the transformation of human beings into commercial objects.

A comparison of growth and per capita growth rates in countries of the South (excluding China) show they were much slower in the 20-year period between 1980-2000 when neoliberalism was at its height, than in the preceding 20-year period from 1960 to 1980 (5.5\% and $3.2 \%$ in $1960-1980$ versus $2.6 \%$ and $0.7 \%$ in $1980-2000) .{ }^{20}$ The same was true for developed countries. ${ }^{21}$ Quality of life and human well-being indicators too reveal more rapid improvement in the preceding period. ${ }^{22}$

The defining feature of neoliberalism is a dramatic increase in inequality in income and wealth within and between countries, a phenomenon that had been on the decline for 60 years. Unemployment, underemployment and job insecurity have become widespread, with the worsening of living and working conditions of the majority, worldwide. Wealth and income have not 'trickled down,' but up, in spite of much slower economic growth in the neoliberal period. The rate of exploitation has significantly risen with

\footnotetext{
${ }^{18}$ See Damien Cahill, The End of Laissez-Faire? On the Durability of Embedded Neoliberalism, Cheltenham, Edward Elga, 2014.

${ }^{19}$ See Alfredo Saad-Filho, Crisis in neoliberalism or crisis of neoliberalism?, op.cit.

20 World Bank, World Development Indicators, 2001 CD-ROM; Robert Pollin, Contours of Descent (Verso, 2003) 131.

${ }^{21}$ World Bank, World Development Indicators, 2001.

${ }^{22}$ Mark Weisbrot, Dean Baker, and David Rosnick, The Scorecard on Development, Center for Economic and Policy Research, Washington, September 2005.
} 
financialisation, reflected in the corresponding decline in the wage share of national income in most countries. Since 1980, the annual income of the top $1 \%$ has increased by $205 \%$ and of the top $0.001 \%$ by $636 \%$, whereas the average annual wage growth of the bottom $50 \%$ has been zero. ${ }^{23}$ Since 2015 , the richest $1 \%$ owns more wealth than the remaining $99 \% .^{24}$

Sayer shows how neoliberal financialisation has supplanted earned income with unearned income over the past four decades, resulting in a transfer of wealth not only from the poor to the rich, but from those producing goods or services to those controlling existing assets and harvesting rent, interest or capital gains. As with privatisation of public services where, in Britain for instance, tollbooths charge rent from State and people for essential assets, the growing indebtedness of the poor and the middle classes has increased bank revenue as well as the oligarchy's control over yet another crucial asset, money. ${ }^{25}$

\section{Myth of an Efficient Private Sector}

The most important study conducted on the efficiency of all European State enterprises privatised between 1980-2009 revealed that they performed worse than those that had remained public. ${ }^{26}$ This was true even for the extremely competitive telecommunications sector where private sector performance was found to be "significantly worse". ${ }^{27}$ A 2015 UNDP study found no model of ownership (public, private, or mixed) intrinsically more efficient than the other, and drew attention to cities in Europe reclaiming public services from the private sector in areas such as water, transportation, electricity, garbage collection, etc. ${ }^{28}$

A telling case is British Metronet Rail which became insolvent before the 5-year Public Private Partnership (PPP) deal ended and was brought under court administration, costing the public over $£ 400$ million. The UK House of Commons Transport Committee, reviewing the PPP in 2008, concluded:

"the Metronet contract did nothing more than secure loans, 95\% of which were in any case underwritten by the public purse, at an inflated cost ... Metronet's

\footnotetext{
232018 World Inequality Report.

24 Credit Suisse (2016) „Global Wealth Databook 2016“. http://publications.creditsuisse.com/tasks/render/file/index.cfm?fileid=AD6F2B43-B17B-345E-E20A1A254A3E24A5

${ }^{25}$ Andrew Sayer, Why We Can't Afford the Rich, Bristol University Press, 2014.

${ }^{26}$ PSIRU, Public and private sector efficiency, May 2014, nin.tl/PSIRU-efficiency $\supseteq$

27 https://impact.vice.com/en_us/article/bjx543/european-cities-are-taking-back-public-services-fromprivate-companies

${ }^{28}$ UNDP, Is the private sector more efficient? A cautionary tale, The Global Centre for Public Service Excellence, UNDP, 2015.
} 
inability to operate efficiently or economically proves that the private sector can fail to deliver on a spectacular scale. ${ }^{29}$

It exploded the myth about private sector efficiency:

"We are inclined to the view that the model itself was flawed and probably inferior to traditional public-sector management. We can be more confident in this conclusion now that the potential for inefficiency and failure in the private sector has been so clearly demonstrated. In comparison, whatever the potential inefficiencies of the public sector, proper public scrutiny and the opportunity of meaningful control is likely to provide superior value for money. Crucially, it also offers protection from catastrophic failure. It is worth remembering that when private companies fail to deliver on large public projects they can walk away-the tax payer is inevitably forced to pick up the pieces. "30

\section{Transfer of Wealth and Power to Global Corporates; Emergence of a Transnationalised Elite}

Past decades have witnessed a massive transfer of wealth, resources, and power from public institutions to foreign corporates. In 2016, the 10 largest TNCs earned more than all countries in the world, their total worth US \$ 285 billion equivalent to the wealth of 180 countries with Walmart, Apple and Shell alone earning more than the majority. ${ }^{31}$ According to a 2017 Oxfam report, 8 men owned as much wealth as 3.6 billion people who make up the poorest half of the global population. ${ }^{32}$

A 2011 study of 43,000 transnational corporations by the Swiss Federal Institute of Technology found that less than $2 \%$ of mostly financial institutions controlled $80 \%$ of the value of all the world's companies, with less than $1 \%(0,34 \%)$ owning interlocking stakes controlling together $40 \%$ of the wealth of the network. ${ }^{33}$ The top 20 included Barclays Bank, J. P. Morgan Chase \& Co, and The Goldman Sachs Group. ${ }^{34}$ The power of finance is such that during the 2008 financial crisis several governments were forced to nationalise some of the world's largest financial institutions and pump public money into the economy. ${ }^{35}$

\footnotetext{
${ }^{29}$ Report of the UK House of Commons Transport Committee, January 2008, HMSO.

${ }^{30}$ Ibid.

${ }^{31}$ Sputnik news, 13 Sept 2016.

${ }^{32}$ An Economy for the 99\%, An Oxfam Briefing Paper, January 2017.

${ }^{33}$ The 147 Companies That Control Everything, Forbes, 22 October 2011.

${ }^{34}$ Andy Coghlan and Debora MacKenzie, Revealed - the capitalist network that runs the world, New Scientist, 19 October 2011.
}

${ }^{35}$ See Alfred Saad-Filho, Crisis in Neoliberalism or Crisis of Neoliberalism? Socialist Register, 2011. 
Corporate influence over especially countries of the Global South manifests itself through sheer economic power, the ability to manipulate transfer prices through intra-company trade (inflating import prices and underpricing exports also to avoid taxation or circumvent limits to profit repatriation), and through the ability to wield influence in the political affairs of sovereign States. As a result, State's ability to act in the public interest has been greatly undermined and citizens' authority usurped.

Robinson (2011) describes how neoliberalism has caused a shift in dominant power relations within States from nationally-oriented elites to transnationally oriented elites, with the latter becoming integrated across borders to form a new transnational capitalist class grounded in globalised circuits of accumulation with, at its apex, a transnational managerial elite. It is this development, he explains, that underlies a shift to a discourse that no longer defines development as national industrialisation and expanded consumption, but in terms of global market integration. ${ }^{36}$

\section{Repression, Manipulation and Retrogression}

To ensure the stable social order demanded by corporates, neoliberalism have, in addition to the repressive State apparatus, developed sophisticated tools to dissimulate the antipeople neoliberal agenda, intimidate critiques and manipulate the poor majority.

Neoliberal regimes use behavioural economics, a new economic theory that emerged with the rise of neoliberalism in the 1980s, to manage resistance. As per this theory, people often behave irrationally or foolishly against their self-interest due to psychological or neurological biases and need to be nudged to think. ${ }^{37}$ Critiques are dismissed as 'conspiracy theorists' or 'paranoid,' those defending sovereignty or State intervention in the collective interest are accused of totalitarianism, and sometimes successfully silenced.

The neoliberal agenda is always identified with noble goals such as civilisation, human rights, freedom, democracy, development, progress, modern, independent, objective and prosperity. What is left unsaid is that the meanings given are from the perspective of a global oligarchy. Seen from the opposite end of a society where poverty, unemployment, underemployment, and insecurity dominate, it means exactly the opposite.

As noted above, 'markets' do not mean spaces where goods and services are freely bought and sold by producers and consumers, but spaces where large corporations dominate unhindered by regulation or countervailing social forces. Thus, by 'social good' is meant what facilitates capitalist reproduction; by 'development' and 'investment' are meant

\footnotetext{
${ }^{36}$ Robinson, W. I. Global Capitalism Theory and the Emergence of Transnational Elites, Critical Sociology, 1-15, 2011.

${ }^{37}$ Best-known behavioural economists are Richard Thaler, Daniel Kahneman, Amos Tversky, Robert Shiller, Senthil Mullainathan, and Cass Sunstein. See Richard H. Thaler and Cass R. Sunstein, Nudge: Improving Decisions about Health, Wealth and Happiness, Yale University Press, 2008.
} 
what benefits stockholders and the Western oligarchy; by 'free market' or 'nonintervention' is meant a market regulated by States on behalf of transnational capital; by 'international relations' is meant vehicles for creating favourable political, social, and economic infrastructure in the Global South; by 'independence' is meant dependence on corporate funding; and 'objective' and 'impartial' are points of view that promote Western oligarchic interests.

The imposition of this point of view has been made possible by legitimising as 'common sense' the neoliberal agenda dissimulated as a 'civilising mission,' with Western civilisation associated with progress and development. In the late $19^{\text {th }}$ century, US and Great Britain justified colonialism and cultural genocide, their "savage wars of peace," as the "White Man's Burden" to bring "civilisation and progress" to "barbaric nonWestern, non-Christian, non-white peoples." Its modern version is Responsibility to Protect (RtoP),' a controversial notion promoted by Washington to legitimise unilateral, preventive and pre-emptive intervention, including military, in the internal affairs of sovereign States on the pretext of protecting citizens of other countries. It is the notion that underpins actions against Sri Lanka in the Human Rights Council.

Associated as it is with human rights, humanitarian missions, and 'good governance,' who but fanatics, lunatics or the foolhardy can be against such a civilising mission? Inevitability is the thread that runs through all neoliberal discourse. Thus, a doctrine promising choice and freedom is promoted with 'There Is No Alternative' (or TINA), an expression popularised by Margaret Thatcher to combat labour.

\section{SRI LANKA: NEOLIBERAL REPRODUCTION}

It is within this global context that neoliberal intervention in Sri Lanka will be examined. Neoliberalism was introduced in Sri Lanka as early as 1978 when President J.R. Jayawardene opened the country to the globally enforced 'free-market' economy and brought in a Constitution that limited the scope of governance and reduced citizens to consumers or workers permitting economic and social choices to be determined by the needs of corporate capital. Subsequent governments, even of the centre-left, pursued the agenda, albeit less aggressively, failing to provide an alternative, their positions driven by circumstance rather than strategic vision. It was in January 2015, even as neoliberalism was being challenged in the centres of corporate capital, and globally, that it received new impetus with the arrival of President Maithreepala Sirisena and his new government led by MPS member Ranil Wickramasinghe ${ }^{38}$ on a neoliberal Good Governance programme.

\footnotetext{
${ }^{38}$ See Eamonn Butler, A short history of the Mont Pelerin Society. In 2004, MPS held a Special Meeting in Kandalama under Mr. Wickramasinghe's influence, when he was Prime Minister. See also https://www.montpelerin.org/past-meetings-2/
} 
This section will attempt to disentangle the complex, interlinked web of actors engaged in re-engineering of the State, constantly complementing and reinforcing each other to ensure the reproduction of neoliberalism in the country. They are, to borrow from Robinson, Sri Lanka's transnationalised elite, the US Administration, transnational corporations and consultancy firms, and local corporate-backed think tanks linked to MPS and its vast network. The focus of this section will be on three lesser known, albeit visible, institutions claiming independence and impartiality - the Institute for Policy Studies (IPS), Advocata Institute, and Millenium Challenge Corporation (MCC). The bigger picture must not be forgotten, however: direct intervention by Washington, IMF/World Bank, and the European Union are ongoing, in addition to the erosion of national sovereignty arising from the US-led Human Rights Council resolution 30/1. Of significance in this process is the active and open collaboration of Sri Lanka's ruling transnationalised elite under the guise of 'good governance.'

\section{Web of Relations: Think Tanks, Global Corporates, Western Governments, and Sri Lanka's Ruling Transnationalised Elite}

IPS, Advocata and MCC, all three make claims to 'independence' and 'impartiality'; the think tanks also calling themselves 'non-profit.' This assertion may appear as truth only if viewed from the perspective of transnational capital: in Orwellian fashion, they mean dependence on corporates, partiality for the 'single model' and US hegemony, and profit maximisation for the Western oligarchy.

IPS was initially co-financed by the Dutch Government, but its direct and indirect donors have expanded to include Canada, UK and Norway, as well as US corporates, banks and equity funds channelled through the Hewlett Foundation and Bill \& Melinda Gates Foundation. They finance its core activities via The Think Tank Initiative (TTI), a project of the Canadian government-owned International Development Research Centre to promote think tanks in the Global South to influence policy change.

Its Chairman Razeen Sally and Governing Board members hold key positions in Government: Sally as Senior Advisor to Finance Minister Mangala Samaraweera, Indrajit Coomaraswamy as Central Bank Governor, M.I.M. Rafeek as Secretary to the Ministry of Policy Planning and Economic Affairs, S.S. Mudalige as Director General of the Department of National Planning, and at the apex of State power is Board Member Sarath Rajapathirana as President Sirisena's Economic Advisor. Rajapathirana is also Visiting Emeritus Scholar at the neoconservative American Enterprise Institute regarded as the "intellectual command post of the neoconservative campaign for regime change in Iraq."

Advocata was launched at the Lakshman Kadirgamar Institute with, as Chief Guest, the then Deputy Minister of Public Enterprise Development Eran Wickramaratne, presently State Minister of Finance. It does not reveal its funding sources. However, information available on its activities reveals a dependence on funds from major global 
corporates through their Foundations. In 2017, for instance, to accelerate the process of reform in Sri Lanka, it joined two corporate-funded MPS linked institutions - Atlas Network of which it is member ${ }^{39}$ and which receives and disburses huge corporate funds to its network, ${ }^{40}$ and the corporate-funded Fraser Institute ${ }^{41}$ - to launch the latter's Economic Freedom of the World Report, which in turn is funded by Charles Koch Institute of the billionaire Koch brothers. ${ }^{42}$ In 2018, Advocata hosted Ricardo Hausmann, Director of Harvard University's Centre for International Development (HCID) financed by multibillion dollar currency speculator George Soros, whose 'spiritual mentor' Karl Popper was an MPS founder. ${ }^{43}$ Hausmann, a Venezuelan national, has been accused of seeking to destabilise the governments of former Venezuelan President Hugo Chavez and his successor, the current President Nicolas Maduro. Recently, he called for US military intervention in Venezuela to end what he claims is "a humanitarian crisis." 44 The Advocata event was joined by McKinsey \& Company, ${ }^{45}$ the highly controversial US corporate that dominates 'propaganda on the public sector.' ${ }^{46}$ It is noteworthy that the

\footnotetext{
${ }^{39}$ Global Directory-Atlas Network, https://www.atlasnetwork.org/partners/global-directory/south-asia

${ }^{40}$ See https://www.sourcewatch.org/index.php/Atlas_Network

${ }^{41}$ See https://www.sourcewatch.org/index.php/Fraser_Institute

42 See https://www.sourcewatch.org/index.php/Fraser_Institute; and https://www.sourcewatch.org/ index.php/Charles_Koch_Institute

43 Soros advocates a 'New World Order' in which "sovereignty of states must be subordinated to international law and international institutions, ” funding so-called colour revolutions and regime change around the world. See George Soros, The Crisis Of Global Capitalism: Open Society Endangered, Public Affairs, New York,1998.
}

44 Matias Vernengo, Talk of military intervention in Venezuela is absurd, aljazeera.com, 20 February 2018. https://www.aljazeera.com/indepth/opinion/talk-military-intervention-venezuela-absurd180220074231779.html . Hausmann He was Venezuela's Minister of Planning from 1992 to 1993 under President Carlos Andres Perez and his economic advisor in 1989 when harsh neoliberal reforms led to the Caracazo riots in which some 3,000 protesters were killed.

45 See https://www.advocata.org/media-archives/2018/6/17/ricardo-hausmann-on-accessing-knowhow-for-development-video-lecture-and-qa .

${ }^{46}$ Christine Ceridwen Davis, Consultants at work: the propaganda war, University of Warwick, 2009. The company has been involved in several scandals, including Enron, Swissair collapse, the Raj Rajaratnam Galleon hedge fund case, and, more recently, 'the Eskom affair' in South Africa, also called "state capture" or "silent coup." It is heavily involved in advising parties to major corporate bankruptcies and but routinely violates legal requirements to disclose conflicts of interests, including investments by its in-house retirement funds. See Inside McKinsey, Financial Times, 25 November 2011; and, How McKinsey lost its way in South Africa, New York Times, 26 June 2018; McKinsey is Big in Bankruptcy - and Highly Secretive, Wall Street Journal, 27 April 2018, Turnaround Veteran Jay Alix Sues Consulting Giant McKinsey, Wall Street Journal, 9 May 2018; and, McKinsey Investments Weren't Disclosed in Bankruptcy Cases, Wall Street Journal, 19 June 2018. See also Duff McDonald, The Firm: The Story of McKinsey and Its Secret Influence on American Business, Simon \& Schuster, 2014. 
company had been hired by the Prime Minister for US\$ 2,3 million to establish a Central Program Management Unit in his Office for "accelerated economic transformation" and to help prepare a three year Economic Delivery Programme (EDP) for US\$ 3 million. ${ }^{47}$ In 2019, Advocata will host the Atlas Asia Liberty Forum funded by billionaire investor and Christian fundamentalist John Templeton's Foundation, an important patron of Atlas. ${ }^{48}$

$M C C$, like IPS and Advocata, also claims independence, despite being a bilateral US aid agency chaired by the Secretary of State with a Board of Directors that comprises the Treasury Secretary, USAID Administrator, and the US Trade Representative. Its purpose is to influence the regulatory environment and rule of law in the South. $M C C$ has a Project Unit physically located within the newly created strategic Policy Development Unit in the Prime Minister's Office. ${ }^{49}$

\section{MPS Network}

A key actor in neoliberal expansion in Sri Lanka is IPS Chairman, Singapore-based Razeen Sally, who is at once active MPS member (and Hayek Medalist) connected to prominent US and European think tanks and their corporate backers, 'mentor' of Advocata "from the very beginning," 50 senior advisor to the Finance Minister, and close associate of co-Mont Pelerinist Prime Minister Ranil Wickramasinghe.

Sally's vision of society, which he advances through IPS (but also through Advocata), often resorting to ad hominem arguments, is a regression of civilisation. Economic equality is "foolhardy" and "collectivist atavism," according to Sally, what makes the poor suffer "the public sector and trade union domination." ${ }^{51}$ In the same vein, he called NGOs proposing incorporation of economic and social rights as fundamental rights in the Constitution "fellow travelers and useful idiots of diehard collectivists," and their

\footnotetext{
${ }^{47}$ Cabinet appoints Committee to fast track economy, Daily News, 31 March 2017.

${ }^{48}$ For links between Atlas, John Templeton Foundation and Liberty Forum, see See Marie-Laure Djelic and Reza Mousavi, Constructing an Organizational Architecture for the Transnational Diffusion of Ideologies - The Case of Atlas and Neoliberalism,op.cit.

${ }^{49}$ Cabinet approves establishment of Millennium Challenge Corporation Project Unit in SL by Keshala Dias, Newsfirst, 15 March 2017. https://www.newsfirst.lk/2017/03/cabinet-approves-establishmentmillennium-challenge-corporation-project-unit-sl/ MCC manages the US Millenium Challenge Account, which is primarily a policy initiative to influence the regulatory environment and rule of law in the South. The Government's Vision 2015 was unveiled only a few months after Cabinet approved establishment of the unit.

${ }^{50}$ Friedrich-Naumann Stiftung fuer die Freiheit, An Idea Whose Time Has Come: Sri Lanka's Advocata Think Tank to Host Asia Liberty Forum 2019, https://southasia.fnst.org/content/idea-whose-time-hascome

${ }^{51}$ Sally R., State of the State, LMD, 2018. https://lmd.lk/state-of-the-state/
} 
proposal "a terrible idea" to be opposed by "all clear-thinking, public spirited citizens". ${ }^{52}$ Sally was referring to fundamental human and labour rights such as education, food, water, adequate housing, social security, a living wage, decent and safe work, freedom from forced evictions, and a safe, clean and healthy environment, guaranteed in international human rights instruments and ILO conventions, which Sri Lanka is legally bound to respect.

Razeen Sally was appointed IPS Chairman by the Prime Minister in April 2015, only three months after his own appointment. He is closely attached to the most prominent US neoliberal think tank founded by MPS member Ed Crane, the Cato Institute of which he is Adjunct Scholar, Board member of its Centre for Trade Policy Studies, and founder/coDirector of the Cato-related European Centre for International Political Economy, which has links to the most influential US neoconservative think tank Brookings Institution. ${ }^{53}$ Sally is also on the board of other influential think tanks founded by MPS member Antony Fisher: the Institute of Economic Affairs (IEA) that played a vital role in British Prime Minister Thatcher's government ${ }^{54}$ and the Centre for Independent Studies in Sydney. ${ }^{55}$

As for Advocata, US strategic interests are guaranteed by Franklin L. Lavin's presence on the top of its Board. Lavin was President Reagan's Political Director and Deputy Executive Secretary on his National Security Council Staff under Carlucci, a former Deputy Director of the CIA, and Colin Powell.$^{56}$ Advocata's membership in Atlas, which has been involved in regime change and destabilisation in countries of strategic interest to Washington, is also testimony of this affinity. Its Board member Suri Ratnapala was on the MPS Board of Directors from 2008 to $2010 ;{ }^{57}$ he is on the panel of intellectuals appointed by the Prime Minister advising the Steering Committee on the new Constitution. Fredrik Erixon, also Board member, co-founded and co-directs with IPS

\footnotetext{
${ }^{52}$ Sally R, Economic and social rights in the new constitution: A terrible idea, Daily FT, 4 Oct 2016.

${ }^{53}$ See https://lkyspp.nus.edu.sg/docs/default-source/faculty-cv/razeen-sally-cv-aug-2018.pdf?Status= Master\&sfvrsn=f37b6e0a_2 ; \& https://www.atlasnetwork.org/academy/course/webinarthink-tanksrole-in-driving-market-competitiveness-with-razeen-sally

${ }^{54}$ For IEA's influence on Thatcher's triumph and policies, see Marie-Laure Djelic, op.cit.

${ }^{55}$ See https://www.sourcewatch.org/index.php/Antony_Fisher

${ }^{56} \mathrm{https}: / / \mathrm{www}$.advocata.org/profiles/

${ }^{57}$ https://www.advocata.org/profiles/; Mont Pelerin Society, World Heritage Encyclopedia, http://self.gutenberg.org/articles/eng/mont_pelerin_society
} 
Chairman Razeen Sally, the European Centre for International Political Economy. ${ }^{58}$ Senior Visiting Professor of Economics Christopher Lingle is on the MPS 2010 Directory. ${ }^{59}$

$M C C$ works closely with the neoconservative think tank Brookings Institution and Heritage Foundation, one of the most influential US think tanks co-founded by MPS member Edwin Feulner, among the first to be appointed on US President Donald Trump's transition team.

\section{On behalf of neoliberalism}

IPS and Advocata, which has a strong ideological agenda "dedicated to economic development through free-markets," 60 provide the Government with justification for accelerated neoliberal reform. A few months after his appointment as IPS Chair, Sally called for "a decisive shift to markets and globalisation," setting out "a new global economic strategy" and "market reform package" as part of "a bigger agenda to limit the State and expand economic freedom." "61 Government reforms have closely followed this neoliberal agenda and have been incorporated in the Prime Minister's Vision 2025.

Advocata's deeply flawed inaugural report The State of State Enterprises with Razeen Sally as key contributor, ${ }^{62}$ launched at the same time as the think tank itself, plays a crucial role in this regard. It is widely used to justify a wide range of neoliberal reforms - economic, financial, political, institutional, and managerial. According to Atlas, its affiliate is widely influential in this ongoing reform process" and has "spurred" the government's "far-reaching privatisation plans," 63 involving privatisation of all State owned Enterprises (SOEs) and public utilities and their 'marketisation.' A proposed

\footnotetext{
${ }^{58}$ European Centre for International Political Economy, http://ecipe.org/person/fredrik-erixon/ http://ecipe.org/person/fredrik-erixon/; See also Between network and complex organization: The Making of Neoliberal Knowledge and Hegemony by Dieter Plehwe and Bernhard Walpen for direct Mont Pelerin Society link with Timbro where Erixon was Chief Economist ; Thinking allowed?

How think tanks facilitate corporate lobbying, Corporate Europe Observatory, 5 July 2016. https://corporateeurope.org/power-lobbies/2016/07/thinking-allowed

${ }^{59}$ https://www.desmogblog.com/sites/beta.desmogblog.com/files/Mont\%20Pelerin\%20Society\%20Dir ectory\%202010.pdf

${ }^{60} \mathrm{https} / / / \mathrm{www}$. advocata.org/about/

${ }^{61}$ Sally R., A new global economic strategy for Sri Lanka, Daily FT, 17 September 2015.

${ }^{62}$ The State of State Enterprises in Sri Lanka- Inaugural Report 2016, Advocata Institute, 5 May 2016.

${ }^{63}$ See https://www.atlasnetwork.org/news/article/reforming-and-privatizing-state-owned-enterprisesin-sri-lanka; https://www.atlasnetwork.org/partners/global-directory/libertad-y-progreso; and, https:// www.atlasnetwork.org/news/article/ten-wins-in-ten-countries-how-atlas-networks-investments-ineconomic-freedo; and Govt. to go whole hog in privatizing all public enterprises, Mirror Business, 4 August 2016.
} 
Public Enterprise Board Act designed on the Temasek model ${ }^{64}$ will "depoliticise" public enterprises and "make them financially viable," according to Kabir Hashim, Minister of Public Enterprise Development. ${ }^{65}$ The Board will be empowered to, inter alia, "sell or dispose of, turn to account or otherwise deal with any property vested in the public enterprise. ${ }^{66}$ 'Depoliticisation' will bring under corporate control all public activities from which profit can be made, marketise public goods, and remove decision-making on essential activities beyond public reach and domestic accountability.

The motivation behind the report is questionable. Not only was it prepared before Advocata itself existed, but more importantly, it is based on shallow consideration of less than $14 \%$ of SOEs for which data were available for the period prior to 2010 (34 out of 245 SOEs), and even then, scanty. The report's preface admits, "there is no single document from which information on their size or performance can be extracted;" and, yet, neoliberal proponents promote it as the "go to reference" for government action. ${ }^{67}$

Building on the flawed report that he was part of, IPS Chairman Sally proceeded to advocate replacement of Public Utilities Commission Board members with "independent directors." His interview to Advocata clarified that by 'independent,' Sally meant nonSri Lankan: "having independent anybody in Sri Lanka is very difficult at the moment," the model to be followed, Temasek companies headed by foreign CEOs. ${ }^{68}$ Sally's neoliberal agenda does not qualify nationals from China with a State-centred economy. ${ }^{69}$ Speaking at an Advocata forum in December 2016, he argued that liberalisation should encourage investments from the West or India, or else "Sri Lanka could become over-

\footnotetext{
${ }^{64}$ A Singapore-based global investment company headquartered in Singapore, which is presented as model for "depoliticising" SOEs by governing them through financial holding companies that have the sole aim of maximising profit.

${ }^{65}$ Sri Lanka to set up Public Enterprises Board for managing SOEs, LBO, 30 March 2017.

${ }^{66}$ See Draft legislation of Public Enterprise Development Act ready, The Sunday Times, 17 July 2016 for statement by Eran Wickramaratne, Deputy Minister Public Enterprise Development.

67 See https://www.atlasnetwork.org/news/article/ten-wins-in-ten-countries-how-atlas-networksinvestments-in-economic-freedo

${ }^{68}$ Reforming State Owned Enterprises $-Q \& A$ with Razeen Sally, in The State of State Enterprises in Sri Lanka - Inaugural Report 2016, The Advocata Institute, 5 May 2016. Note the term "independent" is also used in Resolution 30/1 to refer to foreign participation in a hybrid court.

${ }^{69}$ A pilot project in China to let boards of directors, rather than Party and government, appoint senior management has stalled because it reinforces the trend toward 'fake' investments that generates profits by shifting money between existing assets without generating new economic activity. See China rejects Singapore model for state-owned enterprise reform, Financial Times, 20 July 2017. Sally argues further liberalization to encourage investments from the West or India; else "Sri Lanka could become over-dependent on Chinese investments by State firms without productive private sector investments from the West or India." See Razeen Sally, Sri Lanka drifting, window for economic takeoff narrowing, EconomyNext, 21/12/2016.
} 
dependent on Chinese investments by State firms without productive private sector investments from the West or India."70

Advocata also provided the ideological rationale for the Government's so-called 'land reform' programme involving establishment of a land bank to identify pre-cleared land for private investment projects, consideration of land titling, removal of so-called 'archaic' laws, and a comprehensive review of land use/crop mix. ${ }^{71}$ "Reactivation of Dead Capital' was the rationale it provided, a doctrine developed by Peruvian economist and MPS member Hernando de Soto of Property Rights Alliance, an Advocata partner." ${ }^{72}$ By 'dead capital,' Advocata meant the some 987, 000 acres vested in the Land Reform Commission, especially "prime real estate blocks" occupied by schools, government ministries, and other facilities which "greatly outweigh their economic value," including fixed assets occupied by the military, which should be brought under the management of " an independent body free of political influence to minimise corruption. ${ }^{73}$ To validate the process, Advocata organized the above-mentioned launch of the Fraser Institute's annual Economic Freedom of the World Report in which Sri Lanka was given a low ranking for "weaknesses in the legal system and property rights."74

The complicity between Advocata, IPS and MCC is glaring. In April 2017, IPS assisted $M C C$ identify "binding constraints on access to land" by bringing together "experts and stakeholders" to participate in a round-table discussion on land use policy to identify issues faced by investors with regard to access to commercially viable land. ${ }^{75}$ It is significant that $M C C$ 's "land expert" Brad Cunningham is Fellow at the neoconservative US Brookings Institution with which Sally is also associated. Cunningham worked with HCID that helped design Prime Minister Ranil Wickramasinghe's Vision 2025. ${ }^{76}$

IPS and Advocata, in close collaboration with HCID, have also provided the Government with arguments to amend the Immigration Act, ${ }^{77}$ which help circumvent public opposition to liberalising the labour market. ${ }^{78}$ HCID Director Hausmann described

\footnotetext{
${ }^{70}$ Sally R., Sri Lanka drifting, window for economic take-off narrowing, Economy Next, 21/12/2016.

71 'Vision 2025' development programme gets going, Sunday Times, November 26, 2017.

72 For full report, see Sri Lanka should improve climate for export FDI's, trim mega state, free trade: Advocata, EconomyNext, 9 November 2016.

${ }^{73}$ Ibid.

${ }^{74}$ Sri Lanka forum to boost economic freedom, EconomyNext, 11 October 2017.

${ }^{75}$ IPS assists MCC in identifying binding constraints on access to land, The Island, 10 April 2017.

${ }^{76}$ Brookings Institution, https://www.brookings.edu/experts/brad-cunningham/

77 Immigration and Emigration Act to be amended, Hiru News, 10 May 2018. http://www.hirunews.lk/190419/immigration-emigration-act-to-be-amended

${ }^{78}$ No Indian workers under ETCA but entry possible through SL Immigration rules, Sunday Times, 4 March 2018.
} 
national professional associations as hurdles to "foreign experts" moving across firms. ${ }^{79}$ To bolster his argument, he disingenuously presented US automakers, Ford, GM and Chrysler, and Silicon Valley as 'success stories' to be emulated, concealing the fact that during the 2008 - 2010 economic crisis, the US government had to use public money to bailout out the Big Three automakers for over US\$ 80 billion $^{80}$ (and car sales have plunged again); ${ }^{81}$ and that the 1992-2002 Silicon Valley dot.com bubble had led to the 2002 stock market crash and was even larger today. ${ }^{82}$

\section{Espousal of America's Hegemonic Ambition}

Sally's espousal of Washington's cause for global hegemony is not only apparent in his neoliberal discourse, but also in his public writings and speeches, putting into question his independence and impartiality. Soon after his appointment as IPS Chair, he argued that an FTA with the US be given top priority, because it would, inter alia, "geopolitically, cement an alliance with the world's only superpower and 'balancing power' in Asia, which is also a civilised liberal democracy." 83 In a recent article, he argued more forcefully in favour of America's strategic objective of containing China, ${ }^{84}$ named in Pentagon's 2018 National Defense Strategy as potential rival to its global hegemony: ${ }^{85}$

As for Advocata, US strategic interests are represented by Franklin L. Lavin, number one on its Board.

\section{CONCLUDING REMARKS}

It is clear from the foregoing that globalisation (or neoliberalism) is not a natural phenomenon that is progressive and inevitable, a mystic force beyond the reach of human intervention; it is deliberately designed and imposed by an oligarchy to curtail the power of labour, violently if necessary, in its quest for capital accumulation. The biggest barrier

\footnotetext{
${ }^{79}$ Ricardo Hausmann, The knowhow path to Sri Lankan development, DailyFT, 5 September 2018.

80 Kimberly Amadeo, Auto Industry Bailout, The Balance, 30 September 2018. https://www.thebalance.com/auto-industry-bailout-gm-ford-chrysler-3305670

${ }^{81}$ Car Sales End a 7-Year Upswing, With More Challenges Ahead, The New York Times, 3 Jan 2018.

${ }^{82}$ Why the end is coming soon for the biggest tech bubble we've ever seen, says Villanova professor, MarketWatch, 23 May 2018. https://www.marketwatch.com/story/why-the-end-is-coming-soon-forthe-biggest-tech-bubble-weve-ever-seen-2018-05-22. See also The Entire Economy Is MoviePass Now. Enjoy It While You Can, The New York Times, 16 May 2018.

${ }^{83}$ Sally R., A new global economic strategy for Sri Lanka, op.cit.

${ }^{84}$ Sally R., Why Global Order still needs America in Asia, Quadrant, July-August 2017.

${ }^{85}$ Summary of the 2018 National Defence Strategy of The United States of America. Sharpening the American Military's Competitive Edge.
} 
it faces is national sovereignty, although not the State itself, which it seeks to re-engineer and even reinforce to serve its own interests, not the common good.

The use of both "soft" and "hard" power is the means by which neoliberalism is imposed and reproduced under the patronage of a hegemonic power, in this case the United States. Weapons at its disposal range from economic and political conditionalities imposed through supranational institutions it controls (such as IMF/World Bank, WTO, quasi judicial mechanisms for dispute settlement incorporated in bilateral free trade agreements), sanctions, threats, aggression, and military interventions. The more insidious mechanism is the vast ideological apparatus (such as schools and education systems, media, propaganda, think tanks and civil society organisations promoting neoliberal values), the notion of inevitability and the 'there is no alternative' dogma.

Yet, hidden by the media, is that everywhere more and more people and States are realizing that their sovereignty is at stake, that the political space to influence decisionmaking has been dramatically curtailed by marketisation, making them objects not subjects of their destiny and that, consequently, no political independence is possible without economic independence. People and States everywhere are actively experimenting in concrete and original ways with new forms of production, distribution, exchange and consumption, based on principles of cooperation, sharing and solidarity; its political expression is reflected in movements for national autonomy. At the international level, US hegemony is being challenged as countries of the Global South and Russia establish new forms of cooperation based on principles of multilateralism, cooperation, complementarity, and solidarity; and de-dollarisation gains momentum.

It is equally imperative that the people of Sri Lanka find ways to restore their sovereignty and independence, their best example being the struggle of patriots who fought for international recognition of the most fundamental principle of international law, permanent sovereignty over the nation's wealth, resources and economic activities as a basic constituent of the right of peoples and nations to determine the economic, social, political and cultural systems best suited to their needs and aspirations.

It is these principles that underpin the exceptional international instrument adopted in 1986 by the UN General Assembly, the Declaration on the Right to Development that defines development as "a comprehensive economic, social, cultural and political process, which aims at the constant improvement of the well-being of the entire population and of all individuals on the basis of their active, free and meaningful participation in development and in the fair distribution of benefits resulting therefrom." Its adoption marks an historic turning point, a re-thinking of the concept of 'development' that recognised the widespread failure of the Western, free-market, export-led, foreign debt-dependent, growth-centred model to achieve social progress and wellbeing for all. It rejects the notion of an externally imposed 'single model' based on the superiority of 
Western civilisation as defining progress and development, and calls for an alternative based on principles diametrically opposed to neoliberalism - social justice, equality, nondiscrimination, solidarity and cooperation, not growth, competition, markets, or profit, in which people are the central subjects and architects of their own destiny, not objects producers and consumers.

The Declaration thus stands opposed to neoliberal policies, the trend towards the 'commodification of the world', imposed under the guise of 'laws of the market' as if laws of nature. It defies the individualisation and fragmentation of society, necessary conditions for the creation of markets and profit maximisation, and the individualisation and segmentation of human rights emanating from one and the same process. It sees the human person as an integral and inseparable part of his/her socio-economic, political and cultural environment, made vulnerable to global economic, financial and political changes.

In contemporary society, neoliberalism has, despite itself, contributed to uniting large sections of society, beyond political differences, in a great national struggle for political independence through economic sovereignty. Sri Lanka is no exception.

\section{REFERENCES}

Burgin, A. (2013). The Great Persuasion. Harvard University Press.

Cahill, D. (2014). The End of Laissez-Faire? On the Durability of Embedded Neoliberalism. Cheltenham, UK: Edward Elga.

Cahill, D. \& Saad-Filho, A. (2017). Neoliberalism Since the Crisis. Critical Sociology, 43 (45), 611-613.

Cahill, D. \& Konings, M. (2017). Neoliberalism, Oxford: Polity Press.

Chang, H. J. (2002). Kicking Away the Ladder: Development Strategy in Historical Perspective. London: Anthem Press.

Djelic, M. L. (2014). Spreading Ideas to Change the World - Inventing and Institutionalizing the Neoliberal Think Tank, ESSEC Business School. https://www.researchgate.net/publication/265389761_Spreading_Ideas_to_Change _the_World_Inventing_and_Institutionalizing_the_Neoliberal_Think_Tank_httpssr ncomabstract 2492010 .

Djelic, M. L. \& Mousavi, R. (2016). Constructing an Organizational Architecture for the Transnational Diffusion of Ideologies: The Case of Atlas and Neoliberalism, ESSEC Business School. http://graduateinstitute.ch/files/live/sites/iheid/files/ sites/internationalgovernance/shared/DjelicMousavi2016.pdf

Fine, B. \& Saad-Filho, A. (2016). Thirteen Things You Need to Know About Neoliberalism. Critical Sociology, 43 (4-5), 685-706. 
Sri Lanka Journal of Economic Research Volume 6(1) November 2018

George, S. (2015). Shadow Sovereigns: How Global Corporations are Seizing Power. Cambridge: Polity Press.

Harvey, D. (2005). A Brief History of Neoliberalism. Oxford: Oxford University Press. [í.]"

Kunanayakam, T. (1990). Historical analysis of the principles contained in the Declaration on the Right to Development. HR/RD/1990/CONF.1. Geneva: United Nations.

Kunanayakam, T. (2013). The Declaration on the Right to Development in the context of United Nations standard-setting, Realizing the right to development: essays in commemoration of 25 years of the United Nations Declaration on the Right to Development. United Nations.

Kunanayakam, T. (2007). Quel développement ? Quelle coopération internationale? - La déclaration des Nations Unies sur le droit au développement: Pour un nouvel ordre international. Geneve: Cetim.

Mirowski, P. \& Plehwe, D. (20090. The Road from Mont Pélerin: The Making of the Neoliberal Thought Collective. Harvard University Press.

Peck, J., N. T. \& Brenner, N. (2012). Neoliberalism Resurgent? Market Rule after the Great Recession. South Atlantic Quarterly, 111 (2), 265-288.

Polanyi, K. (2001). The Great Transformation: The Political and Economic Origins of Our Times. Boston: Beacon Press.

Plehwe, D. B. W. \& Neuhöffer, G. (2006). Neoliberal Hegemony: A Global Critique. Routledge.

Roberts, M. (2009). The Great Récession.

Roberts, M. (2009). The Great Recession: Profit Cycles, Economic Crisis: A Marxist View. Available at https://archive.org/details/TheGreatRecession.ProfitCycles EconomicCrisisAMarxistView.

Robinson, W. I. (2011). Global Capitalism Theory and the Emergence of Transnational Elites. Critical Sociology, 1-15.

Saad-Filho, A. (2011). Crisis in neoliberalism or crisis of neoliberalism. Socialist Register, 47(47).

Saad-Filho, A. \& Johnston, D. (2005). Neoliberalism: A Critical Reader. Pluto Press.

Skousen, M. (2005). Vienna and Chicago, Friends or Foes? Regnery Publishing.

Stedman, J. D. (2012). Masters of the Universe. Princeton, NJ: Princeton University Press.

Walpen, B. (2004). Die Offenen Feinde Und Ihre Gesellschaft: Eine Hegemonietheoretische Studie Zur Mont Pelerin Society. Hamburg: Vsa Verlag.

Yergin, D. \& Stanislaw, J. [1998]. The Commanding Heights. NY: Touchstone. 